\title{
The serine protease Omi/HtrA2 is released from mitochondria during apoptosis. Omi interacts with caspase-inhibitor XIAP and induces enhanced caspase activity
}

G van Loo', M van Gurp', B Depuydt', SM Srinivasula ${ }^{2}$, I Rodriguez ${ }^{3}$, ES Alnemri ${ }^{2}$, K Gevaert ${ }^{4}$, J Vandekerckhove ${ }^{4}$, W Declercq ${ }^{1}$ and $P$ Vandenabeele ${ }^{*, 1}$

1 Flanders Interuniversity Institute for Biotechnology and Ghent University, Molecular Signalling and Cell Death Unit, Department of Molecular Biology, K.L. Ledeganckstraat 35, B-9000 Ghent, Belgium

${ }^{2}$ Center for Apoptosis Research and the Department of Microbiology and Immunology, Kimmel Cancer Institute, Thomas Jefferson University, Philadelphia, Pennsylvania 19107, USA

3 The Rockefeller University, Laboratory of Vertebrate Neurobiology, New York, USA

${ }^{4}$ Flanders Interuniversity Institute for Biotechnology and Ghent University, Department of Medical Protein Research, K.L. Ledeganckstraat 35, B-9000 Ghent, Belgium

* Corresponding author: P Vandenabeele, K.L. Ledeganckstraat 35, B-9000 Ghent, Belgium. Tel.: 32-9-264-51-31; Fax: 32-9-264-53-48;

E-mail: peter.vandenabeele@rug.ac.be

Received 12.10.01; revised 18.10.01; accepted 18.10.01 Edited by G Melino

\begin{abstract}
Proteome analysis of supernatant of isolated mitochondria exposed to recombinant tBid, a proapoptotic $\mathrm{Bcl}-2$ member, revealed the presence of the serine protease $0 \mathrm{mi}$, also called HtrA2. This release was prevented in mitochondria derived from Bcl-2-transgenic mice. Release of Omi under apoptotic conditions was confirmed in vivo in livers from mice injected with agonistic anti-Fas antibodies and was prevented in livers from Bcl-2 transgenic mice. Omi release also occurs in apoptotic dying but not in necrotic dying fibrosarcoma L929 cells, treated with anti-Fas antibodies and TNF, respectively. The amino acid sequence reveals the presence of an XIAP interaction motif at the $\mathrm{N}$-terminus of mature $0 \mathrm{mi}$. We demonstrate an interaction between endogeneous $0 \mathrm{mi}$ and recombinant XIAP. Furthermore we show that endogenous Omi is involved in enhanced activation of caspases in cytosolic extracts.

Cell Death and Differentiation (2002) 9, 20-26. DOI: 10.1038/sj/ cdd/4400970
\end{abstract}

Keywords: apoptosis; caspase; mitochondria; tBid; serine protease; Omi; $\mathrm{HtrA2}$

Abbreviations: BIR, Baculovirus IAP repeat; DIABLO, direct IAP binding protein with low pl; MALDI, matrix-assisted laser desorption ionization; MBP, maltose binding protein; MS, mass spectrometry;
PSD, post-source decay; Smac, second mitochondria-derived activator of caspase; tBid, truncated Bid; XIAP, X-linked inhibitor of apoptosis protein

\section{Introduction}

The central players in the apoptotic pathway are the caspases, a family of cysteinyl aspartate specific proteases. Caspases are activated in response to diverse stimuli and cleave multiple cellular substrates resulting in dismantling of the cell. ${ }^{1}$ Due to its destructive nature, caspase activity should be tightly regulated. The main endogenous inhibitors of caspases are members of the inhibitor of apoptosis (IAP) family of proteins such as XIAP (X-linked IAP). ${ }^{2}$ IAP proteins are characterized by the presence of one, two or three baculovirus IAP repeat (BIR) domains. Several IAPS also have a RING-finger domain at their carboxyl terminus. Although some BIR-domain containing IAP proteins such as Bruce and Survivin can regulate cytokinesis and mitotic spindle formation, IAP proteins seem to be mainly involved in the binding and inhibition of active caspases. ${ }^{3}$ XIAP physically interacts with activated caspases-3, -7 and -9 and blocks the enzymatic activity through its BIR domains. ${ }^{2}$ Recently it was shown that the BIR2 domain and its adjacent $\mathrm{N}$-terminal sequence are essential for binding of caspases-3 and $-7,{ }^{4-6}$ while the BIR3 domain of XIAP interacts with a conserved motif at the $\mathrm{N}$-terminus of the caspase-9 small subunit. ${ }^{7}$ DIABLO/Smac, a mitochondrial protein that is released in apoptosis, may destabilize these complexes. ${ }^{8,9}$ This leads to quenching of the caspaseinhibitory function of XIAP by competitive interaction with the BIR domains. ${ }^{7,10-12}$ After triggering of death receptors such as TNF-R1 and Fas, procaspase-8 is activated resulting in Bid cleavage generating truncated Bid (tBid) that translocates to mitochondria releasing apoptogenic proteins such as cytochrome $c$ and DIABLO/Smac. ${ }^{13}$ Studying the mitochondrial release of such proteins during tBid-treatment of isolated mitochondria, ${ }^{14}$ we identified the serine protease Omi as a potential new player in this complex interaction between caspases, inhibitors and regulatory proteins. Omi, also named $\mathrm{HtrA}$, was identified as the mammalian homologue of the bacterial HtrA endoprotease and is highly conserved from bacteria to mammalians. ${ }^{15-17}$ The mammalian orthologue HtrA2/Omi is upregulated during renal ischemia-reperfusion ${ }^{16}$ and is putatively involved in cell growth regulation. ${ }^{15}$ Although reported as being localized either within the endoplasmic reticulum ${ }^{16}$ or the nucleus, ${ }^{17}$ we identified Omi as a protein released in vitro from isolated mitochondria treated with 
recombinant $\mathrm{tBid}{ }^{14}$ This translocation could be confirmed in apoptotic models in vivo and in a fibrosarcoma cell line. This mitochondrial release of Omi was completely prevented by Bcl-2. Moreover, under necrotic cell death conditions no such translocation is observed. The exposed $\mathrm{N}$-terminal sequence of mature Omi contains a conserved XIAPinteraction motif. ${ }^{7}$ We could demonstrate that Omi interacts with recombinant XIAP, preventing the caspase-inhibitory function of the latter.

\section{Results \\ tBid is required and sufficient for the release of Omi from isolated mitochondria}

In order to study tBid-mediated release of proteins from mitochondria in a systematic way, we performed a proteome analysis on supernatant of isolated mitochondria treated with purified recombinant tBid. ${ }^{14}$ One of the proteins identified by mass spectrometry and PSD analysis ${ }^{18}$ was the serine protease Omi (Figure 1). Although Omi has a theoretical

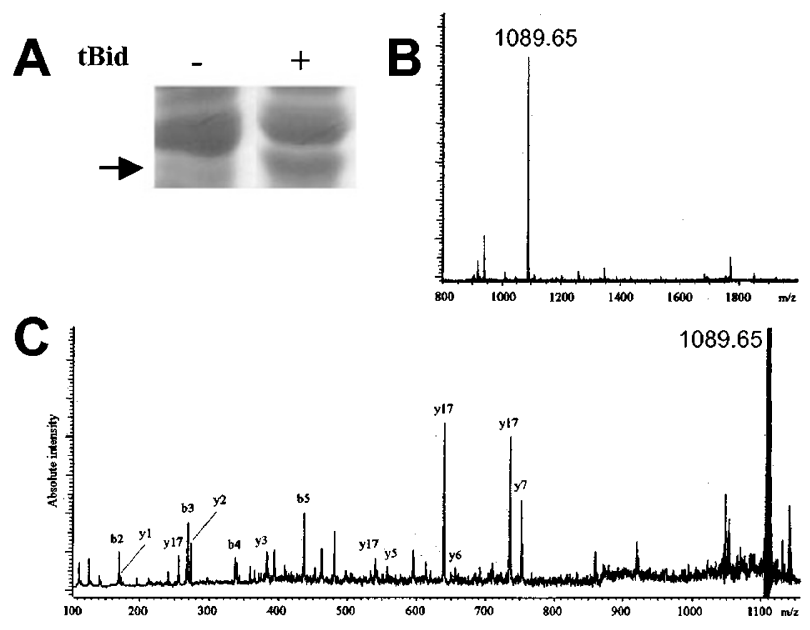

D MAALKAGRGA NWSLRAWRAI GGIEWRKPPI, LAPDLRALIT SGTPDSQIWM TYGTPSLPAQ VPEGFLASRA DLTSRTPDLW ARLNVGTSGS SDQEARRSPG SRRREWLAVA VGAGGAVVLL LWGWGRGLST VLAAVPAPPP TSPRSQYNFI ADVVEKTAPA VVYIEILDRH PFSGREVPIS NGSGFVVASD GLIVTNAHVV ADRRRVRVRL PSGDTYEAMV TAVDPVADIA TLRIQTKEPL PTLPLGRSAD VRQGEFVVAM GSPFALQNTI TSGIVSSAQR PARDLGLPQN NVEYIQTDAA IDFGNSGGPL VNLDGEVIGV NTMKVTAGIS FAIPSDRLRE ELHRGEKKNS WFGTSGSQRR YIGVMMLTLT PSILIELQLR EPSFPDVQHG VLIHKVILGS PAHRAGLRPG DVILAIGEKI AQNAEDVYEA VRTQSQLAVR IRRGSETITL YVTPEVTE

Figure 1 Identification of Omi. (A) A mitochondrial preparation of one mouse liver treated with tBid was subjected to $15 \%$ SDS-PAGE and stained with Coomassie Brilliant Blue. The arrow indicates a $37 \mathrm{kDa}$ protein band released from mitochondria. (B) MALDI-MS spectrum of peptides present in the HPLCfraction from trypsin digests of the $37 \mathrm{kDa}$ band. (C) MALDI-PSD analysis of the peptide with a mass of $1089.65 \mathrm{Da}$ present in the spectrum of $(B)$ led to the identification of the mouse Omi protein. (D) Amino acid sequence of Omi protein. The $\mathrm{N}$-terminal presequence (underlined) contains a mitochondrial targeting sequence (double underlined). The tryptic peptide identified in (C) is highlighted in bold molecular weight of $49 \mathrm{kDa}$, the protein that is identified in mitochondria has a size of $37 \mathrm{kDa}$ as the $\mathrm{N}$-terminal presequence is probably cleaved off after mitochondrial transport producing mature Omi (Figure 1D). This N-terminal presequence contains a mitochondrial targeting sequence as predicted by using the MITOPROT computational method. ${ }^{19}$ The presence of this serine protease was obvious in supernatant of purified mitochondria exposed to tBid, as shown by Western blotting (Figure 2A). The release of Omi was completely prevented in mitochondria from $\mathrm{Bcl}-2$ transgenic mice at a concentration of tBid of $10 \mathrm{ng}$, corresponding to $6.7 \mathrm{nM}$ (Figure 2A). As caspase-8 cleaves endogenous Bid under apoptotic conditions, ${ }^{20,21}$ we prepared cytosols from untreated L929sAhFas cells and exposed these extracts to recombinant caspase- 8 . When incubated with purified mitochondria, this activated cytosol was able to induce the release of Omi (Figure 2B). Immunodepletion of Bid from L929sAhFas cytosol activated with recombinant caspase- 8 completely abrogated the release of this protease (Figure 2B) indicating that endogenous levels of Bid are sufficient and essential for Omi release from mitochondria. Identical results were obtained for the release of cytochrome $c$ (Figure 2B).

\section{Omi translocates from mitochondria to the cytosol during apoptosis}

The observation that isolated mitochondria release Omi when treated with proapoptotic tBid could be confirmed in vivo in a murine model of experimental lethal hepatitis. Administration of agonistic anti-Fas antibodies to mice induced the release of both Omi and cytochrome $c$ from the mitochondria to the cytosol. This mitochondrial release was completely absent in Bcl-2 transgenic mice (Figure 2C). L929sAhFas cells were shown to die either by apoptosis when stimulated with anti-Fas, or by necrosis when stimulated with $\mathrm{TNF}^{22}$ so both cell death pathways occur in the same cellular context depending on the extracellular stimulus. Omi release into the cytosol was restricted to cells that die by apoptosis when exposed to anti-Fas, as was shown previously for cytochrome $c .^{23}$ No Omi nor cytochrome $c$ release was seen in necrotic dying cells when stimulated with TNF (Figure 2D). This observation is related with the absence of tBid generation in necrotic cell death (Figure 2D), illustrating once more the profound difference in the functional role of mitochondria in both ways of cell death.

\section{Omi binds to XIAP and promotes caspase activity}

After transport into the mitochondria, the N-terminal 133 amino acid peptide of Omi is cleaved off generating the mature protein. ${ }^{24}$ Sequence comparison of the $\mathrm{N}$-terminus of the mature mouse and human Omi protein revealed the presence of the conserved XIAP BIR3-interaction motif AVPA and AVPS, respectively. This conserved IAP-binding motif is also seen at the N-terminus of the small subunit of mature caspase-9 and mature DIABLO/Smac (Figure 3A) and it was also described for the Drosophila proteins Reaper, Hid and Grim. ${ }^{7}$ To determine if released $\sim 37 \mathrm{kDa}$ Omi can 
A.

wild-type mitochondria
Bcl-2 mitochondria

Omi (37 kDa)

B.

$\begin{array}{rrrrrr}\text { cytosol } & - & + & + & + & + \\ \text { caspase-8 } & - & - & + & - & + \\ \text { Bid depletion } & - & - & - & + & +\end{array}$

Omi (37 kDa)

cytochrome c (14 kDa)

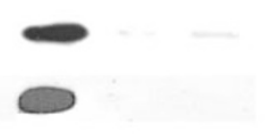

C.

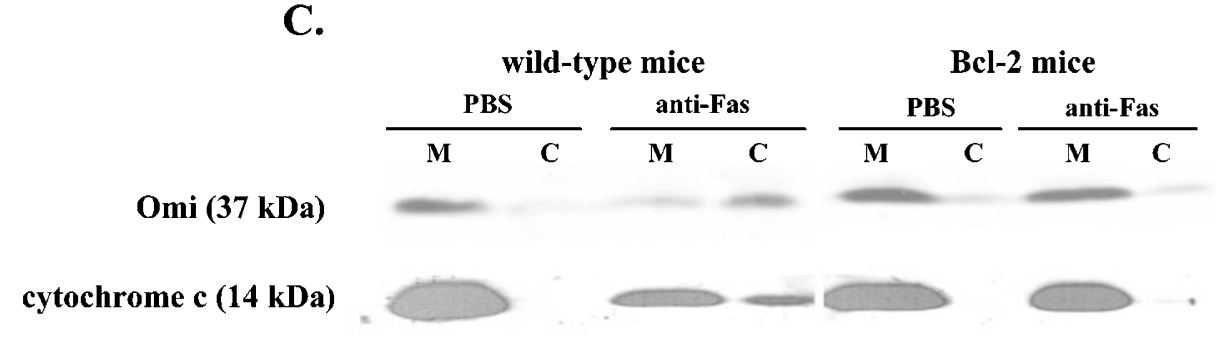

D.

L929sAhFas

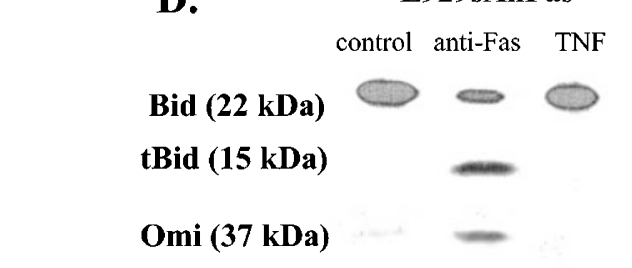

cytochrome c (14 kDa)

Figure 2 tBid is sufficient and required for mitochondrial Omi release. (A) tBid was incubated with purified liver mitochondria from wild-type and Bcl-2 transgenic mice. Supernatants were separated from the mitochondrial pellets by centrifugation and subjected to SDS-PAGE, followed by immunoblotting with anti-Omi antibody. (B) Endogeneous Bid was immunodepleted from L929sAhFas cytosol activated with recombinant caspase-8 (1 $\mu \mathrm{g})$ prior to incubation with mitochondria, as indicated. Supernatants were isolated and subjected to SDS-PAGE followed by immunoblotting with anti-Omi and anti-cytochrome $c$ antibodies. (C) Wild type and Bcl-2 transgenic mice were intravenously injected with PBS or agonistic anti-Fas antibody and liver mitochondria were prepared as described in Materials and Methods. $100 \mu \mathrm{g}$ of mitochondrial (M) and cytosolic (C) lysates were subjected to SDS-PAGE, followed by immunoblotting with anti-Omi or anti-cytochrome $c$ antibodies. (D) Non-treated L929sAhFas control cytosol, anti-Fas antibody-induced (250 ng/ml) L929sAhFas apoptotic cytosol and mTNF-induced (10000 U/ml) L929sAhFas necrotic cytosol were prepared using digitonin lysis buffer and immunoblotted with anti-Omi antiserum and anti-cytochrome $c$ antibody. To monitor Bid proteolysis total lysates were prepared

bind to XIAP, we performed an in vitro interaction assay in which control and tBid-induced mitochondrial supernatants were incubated with either maltose binding protein (MBP) or with the N-terminal MBP-XIAP fusion protein. Following pull down of the protein complexes with amylose beads, Western blotting revealed the presence of Omi in case of MBP-XIAP. No Omi was found in the condition using MBP protein alone as a control for aspecific binding to MBP and the amylose beads (Figure 3B). It has been reported that DIABLO/Smac disrupts the interaction between processed caspase- 9 and
BIR3-XIAP leading to the activation of downstream executioner caspases. ${ }^{7}$ The same could be true for Omi. Therefore, we examined the ability of the tBid-induced mitochondrial supernatant to promote activation of endogenous caspases in L929sAhFas cytosol. This cytosol contains high levels of XIAP (data not shown). tBid-induced mitochondrial supernatant could induce the activation of endogenous executioner caspases demonstrated by an increase in DEVDase activity (Figure 4B). To test whether Omi was involved in the generation of this caspase activity, 
A.

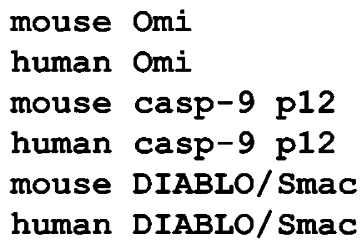

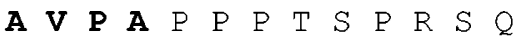

$\begin{array}{llllllllllllll}A & \boldsymbol{V} & \mathbf{P} & \mathbf{S} & \mathrm{P} & \mathrm{P} & \mathrm{P} & \mathrm{A} & \mathrm{S} & \mathrm{P} & \mathrm{R} & \mathrm{S} & Q\end{array}$

$\begin{array}{lllllllllllll}A & V & P & Y & Q & E & G & P & R & P & L & D & Q\end{array}$

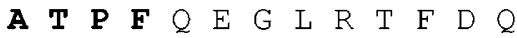

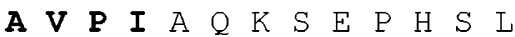

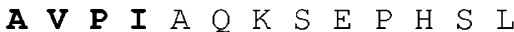

B.

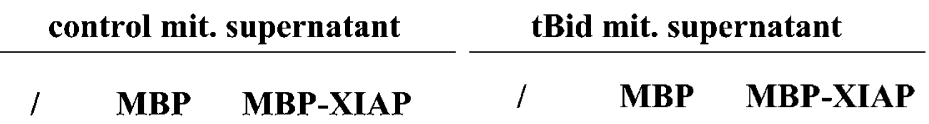

Omi (37 kDa)

Figure 3 Omi interacts with XIAP (A) Alignment of the N-terminal sequences of mouse and human Omi, caspase-9 p12 subunit and DIABLO/Smac. The XIAPbinding motif is highlighted in bold. (B) Control and tBid-induced mitochondrial supernatants were left untreated, incubated with MBP control or MBP-XIAP as indicated. Protein complexes were isolated with amylose beads and subjected to SDS-PAGE followed by immunoblotting with anti-Omi antibody



Omi (37 kDa)

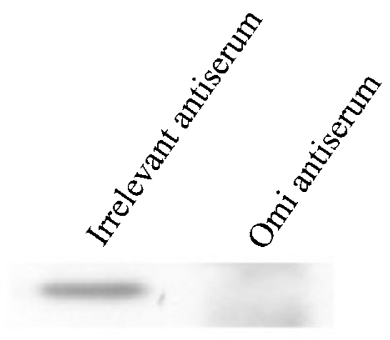

B

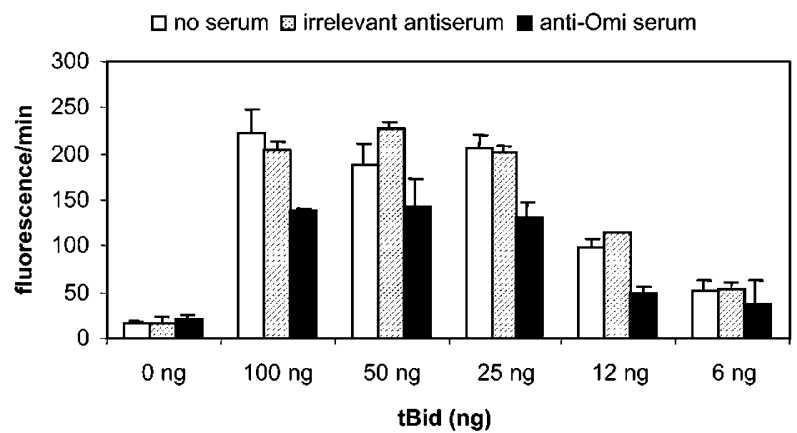

Figure 4 Omi release leads to enhanced caspase activity (A) Immunoblotting with anti-Omi antiserum of tBid-induced mitochondrial supernatant after depletion of Omi with anti-Omi serum. As a control the supernatant was incubated with an irrelevant antiserum. (B) $50 \mu \mathrm{g}$ L929sAhFas cytosol was incubated with mitochondrial supernatant, induced with different amounts of tBid as indicated. tBid-induced mitochondrial supernatant was left untreated or immunodepleted with anti-Omi serum. As a control an irrelevant antiserum was used. Caspase activity was measured using Ac-DEVD-amc as a substrate

Omi was immunodepleted from the mitochondrial supernatant. This resulted in reduced DEVDase activity. An analogous treatment with irrelevant antiserum had no effect
(Figure 4A,B). This suggests that Omi plays a proapoptotic role by enhancing caspase activity.

\section{Discussion}

Mitochondria are now recognized as central players in the control of cell death mainly through the release of several proapoptotic intermembrane space proteins. ${ }^{25}$ These proteins include cytochrome $c,{ }^{26}$ apoptosis inducing factor, ${ }^{27}$ endonuclease $\mathrm{G}^{28,29}$ and the recently identified DIABLO/Smac. ${ }^{8,9} \mathrm{We}$ have reported on the identification of proteins released from isolated mitochondria treated with purified recombinant tBid. One of these proteins was identified as Omi by mass spectrometry and PSD analysis. ${ }^{14}$ Omi was recently described as a member of a novel family of mammalian serine proteases homologous to the bacterial HtrA gene product. This serine protease has been described in a wide range of bacteria and eukaryotes and is evolutionary well conserved. ${ }^{15-17}$ Bacterial HtrA was shown to act as a chaperone below $28^{\circ} \mathrm{C}$ and as an active protease above $37^{\circ} \mathrm{C}^{30}$ In mammalians, HtrA2/Omi is involved in the degradation of aberrantly folded proteins during conditions of cellular stress such as endoplasmatic reticulum stress, heat shock and ischemia-reperfusion, ${ }^{16,17}$ but was also proposed to play a role in cell growth regulation. ${ }^{15}$ Although originally reported as localized in the endoplasmic reticulum ${ }^{16}$ or the nucleus, ${ }^{17}$ we detect Omi in isolated mitochondria with an apparent molecular weight of $37 \mathrm{kDa}$. The precursor form of Omi has a theoretical molecular weight of $49 \mathrm{kDa}$. This precursor form contains a mitochondrial localization signal, as predicted using a computational model. ${ }^{19}$ During mitochondrial import the first $133 \mathrm{~N}$-terminal amino acids are removed generating mature Omi protein. ${ }^{24}$ This processing leads to the $\mathrm{N}$-terminal exposition of a conserved AVPA sequence, which can allow interaction with the BIR3-domain in XIAP. A similar interaction was previously described for DIABLO/Smac, 
caspase-9 and the Drosophila proteins Hid, Grim and Reaper. ${ }^{7}$ We could confirm this predicted binding by pull down experiments using recombinant MBP-XIAP and revelation with anti-Omi antiserum. Recently, structure/ function analysis of the Omi-XIAP interaction showed that binding could occur both with the BIR2 or the BIR3 domain. ${ }^{31}$ Besides its interaction with XIAP, we showed that the release of Omi could also increase caspase activity in L929sAhFas cytosol.

Omi interacts with XIAP in a similar way as DIABLO/Smac and both are of mitochondrial origin. However, what could be the difference between both proteins and what could be the role of the redundant mechanism of XIAP regulation? $A$ possible clue might be the differential expression pattern of both proteins. Northern analysis showed that DIABLO/Smac mRNA was most abundant in heart, liver, kidney and testis but expression was not readily detectable in skeletal muscle, lung, thymus and brain. ${ }^{8,9}$ Omi mRNA, however, is expressed ubiquitously. ${ }^{16,17}$ However, another important feature that differentiates Omi from DIABLO/Smac is its serine protease activity. Although no specific activation mechanism or functional substrates were reported so far, it seems that Omi is strongly cytotoxic depending on its catalytic serine while overexpression of DIABLO/Smac is not. $^{31}$ Overexpression of Omi causes an atypical caspaseindependent cell death. ${ }^{31}$ Although the cytotoxic activity of a protease after transient overexpression may not be relevant, it is suggestive that Omi may have a bifunctional potential: one as inhibitor of XIAP, propagating caspase cascades, and another one as a serine protease, propagating atypical caspase-independent cell death. ${ }^{31}$ Some studies described a role for serine proteases in the apoptotic cell death process. ${ }^{32,33}$ Also in necrosis, which is generally considered as a caspase-independent process, serine proteases may be involved. ${ }^{22}$ However, the implication of mitochondrial Omi in necrosis is not very likely in view of our data that demonstrate that during TNF-induced necrosis in L929sAhFas cells no release of Omi could be observed. This does not exclude that the serine protease Omi at other subcellular localizations, such as endoplasmatic reticulum ${ }^{16}$ or nucleus ${ }^{17}$ may be involved. To conclude, our data show that Omi is released from mitochondria during apoptosis, interacts with XIAP and promotes caspase activation. Although its catalytic site seems to be essential for its cell death promoting activity as was shown in overexpression experiments, ${ }^{31}$ the relevance of its protease activity is still unclear. Identification of possible substrates and inhibitors of Omi and its mechanism of activation will be of crucial importance.

\section{Materials and Methods}

\section{Animals, cells and reagents}

C57BL/6 wild type and liver-specific Bcl-2 transgenic mice ${ }^{34}$ were used at the age of 7-12 weeks. Monoclonal hamster anti-mouse Fas antibody Jo2 (Pharmingen, San Diego, CA, USA) was dissolved in endotoxin-free PBS and injected intravenously (15 g in $200 \mathrm{I} \mathrm{per}$ mouse). Livers from sacrificed mice were homogenized on ice (5 mM $\mathrm{KH}_{2} \mathrm{PO}_{4} \mathrm{Ph}$ 7.4, $0.3 \mathrm{M}$ sucrose, $1 \mathrm{mM}$ EGTA, $5 \mathrm{mM}$ MOPS).
L929sAhFas cells were cultured in Dulbeco's Modified Eagle Medium (DMEM), supplemented with penicillin $(100 \mathrm{U} / \mathrm{ml})$, streptomycin $(0.1 \mathrm{mg} / \mathrm{ml})$, L-glutamine $(0.03 \%)$ and fetal calf serum (10\%). Cells were left untreated, stimulated with $250 \mathrm{ng} / \mathrm{ml}$ agonistic anti-human Fas antibody (clone 2R2, Cell Diagnostica, Menster, Germany) for $30 \mathrm{~min}$ to $2 \mathrm{~h}$ or with $10000 \mathrm{U} / \mathrm{ml}$ recombinant murine TNF (produced in our laboratory by Alex Raeymaeckers) for 2-7 h. Cells were washed in ice-cold PBS and permeabilized in $0.02 \%$ digitonin (Boehringer Mannheim $\mathrm{GmbH}$, Mannheim, Germany) dissolved in cell free system buffer (CFS) (10 mM HEPES- NaOH pH 7.4, $220 \mathrm{mM}$

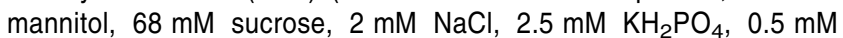

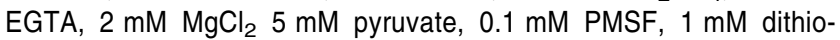
threitol) and left on ice for $1 \mathrm{~min}$. This treatment allows selective lysis of the outer cell membrane without affecting the organelle membranes. Lysates were cleared by centrifugation at $20000 \times g$ for $10 \mathrm{~min}$ and stored at $4^{\circ} \mathrm{C}$.

\section{Expression and purification of recombinant proteins}

Murine tBid (residues 60-195) with a tag of six histidines at the Nterminus was cloned in the pLT10 vector and expressed in Escherichia coli. The protein was recovered in the soluble bacterial fraction and purified by cobalt-immobilized metal affinity chromatography (TA$\mathrm{LON}^{\circledR}$, Clontech, Palo Alto, CA) using the manufacturer's protocol. Active recombinant murine caspase- 8 was expressed and purified by a similar method. ${ }^{35}$ XIAP was cloned in frame to the maltose binding protein (MBP) coding region on the PMAL-c2X bacterial expression vector (New England Biolabs, Beverly, MA, USA). Bacteria were grown for $16 \mathrm{~h}$ with $0.2 \mathrm{mM}$ isopropyl $\beta$-D-thiogalactopyranoside (IPTG) at $20^{\circ} \mathrm{C}$ and sonicated in $20 \mathrm{mM}$ Tris- $\mathrm{HCl} \mathrm{pH} 7.5$ and $100 \mathrm{mM}$ $\mathrm{NaCl}$ supplemented with complete EDTA-free protease inhibitor (Roche, Mannheim). SDS-PAGE, Coomassie brilliant blue staining and Western analysis showed the presence of the MBP-XIAP fusion protein in the soluble fraction. As a control sonicated bacteria containing $\mathrm{PMAL}-\mathrm{C} 2 \mathrm{X}$ and expressing MBP were used.

\section{Isolation of murine liver mitochondria}

Livers of wild-type and $\mathrm{Bcl}-2$ transgenic mice were homogenized and mitochondria were prepared as described earlier, ${ }^{14}$ resuspended in CFS buffer, kept on ice and used within $1 \mathrm{~h}$ after preparation.

\section{MALDI-PSD protein identification}

Identification of Omi from tBid-induced mitochondrial supernatant was performed as described previously. ${ }^{14}$

\section{Western blot analysis of tBid-induced release of mitochondrial proteins}

Intact mouse liver mitochondria equivalent of $40 \mu \mathrm{g}$ protein were incubated at $37^{\circ} \mathrm{C}$ in $100 \mu \mathrm{l} \mathrm{CFS}$ buffer for $20 \mathrm{~min}$ with various reagents as indicated in the figure legends. The supernatants were separated from the mitochondria by centrifugation at $20000 \times g$ for $10 \mathrm{~min}$ at $4{ }^{\circ} \mathrm{C}$. One fifth of the supernatant was subjected to $15 \%$ and $12.5 \%$ SDS - PAGE followed by Western blotting with anti-cytochrome $C$ antibody (clone $7 \mathrm{H} 8.2 \mathrm{C} 12$, Pharmingen, $\mathrm{CA}$, USA) or an antibody raised against $\mathrm{Omi}$, respectively. Blots were visualized with the chemiluminescence NEN Renaissance method (Du Pont, Wilmington, DE, USA) after incubation of membranes with secondary antibody coupled to horseradish peroxidase (Amersham Pharmacia Biotech, Rainham, UK). 


\section{Immunodepletion and coprecipitation experiments}

For immunodepletion of tBid, L929sAhFas digitonin lysates were precleared 3 times by incubation for 5 min with $20 \%$ protein $\mathrm{G}$ beads (Amersham Pharmacia Biotech, Rainham, UK) and incubated with anti-Bid antibody (10 $\mu \mathrm{g} 5 \times 10^{6}$ cells) (R\&D Systems Inc., Minneapolis, MN, USA) for $1.5 \mathrm{~h}$ at $4^{\circ} \mathrm{C}$. The antibody complexes were captured with protein $\mathrm{G}$ beads ( $20 \%$ slurry) for $30 \mathrm{~min}$ at $4^{\circ} \mathrm{C}$ and removed by centrifugation. The resulting Bid-depleted supernatant was used in the reconstitution experiment with purified liver mitochondria. For immunodepletion of Omi from tBid-induced mitochondrial supernatant a comparable procedure was followed using Tris-Acryl protein A beads (Pierce, Rockford, IL, USA). Pull-down experiments of Omi, control and tBid-induced mitochondrial supernatants were incubated with bacterial sonicate containing $10 \mu \mathrm{g} \mathrm{MBP}$ and MBP-XIAP in CFS buffer for $1.5 \mathrm{~h}$ at $4^{\circ} \mathrm{C}$. MBP-interacting proteins were pulled down by amylose resin (New England Biolabs, Beverly, MA, USA), beads were isolated by centrifugation, washed three times in CFS buffer and boiled in laemli buffer. After centrifugation, the supernatant was separated on $12.5 \%$ SDS-PAGE followed by immunoblotting with anti-Omi antibody.

\section{DEVD-amc cleavage assay}

L929sAhFas cytosol, MBP-XIAP and tBid-induced mitochondrial supernatant were coincubated with $50 \mu \mathrm{M}$ acetyl-Asp-Glu-Val-Aspaminomethylcoumarin (Ac-DEVD-amc) (Peptide Institute Inc., Osaka, Japan) in $150 \mu$ l CFS buffer. The release of fluorescent 7-amino-4methylcoumarin was measured for $50 \mathrm{~min}$ at 2-min intervals by fluorospectrometry at $360 \mathrm{~nm}$ excitation and $480 \mathrm{~nm}$ emission wavelength and the maximal rate of increase in fluorescence was calculated ( $\Delta$ fluorescence/min) (Cytofluor, PerSeptive Biosystems, Cambridge, MA, USA).

\section{Acknowledgements}

We thank Ann Meeuws and Wilma Burm for expert technical assistance and Myriam Goessens and Leen Puimege for animal care. This work was supported in part by the Interuniversitaire Attractiepolen IV/26 and IV/23, the Fonds voor Wetenschappelijk Onderzoek-Vlaanderen (grant 3G.0006.01), the Bijzonder Onderzoeksfonds, and the EC-RTD grant QLRT-1999-00739. Maria van Gurp is a fellow with the Vlaams Instituut voor de Bevordering van het Wetenschappelijk-technologisch Onderzoek in de Industrie. Bart Depuydt received a grant from the Centrum voor Studie en Behandeling van Gezwelziekten and $\mathrm{K}$ Gevaert is a postdoctoral researcher with the Fonds voor Wetenschappelijk Onderzoek-Vlaanderen

\section{References}

1. Earnshaw WC, Martins LM and Kaufmann SH (1999) Mammalian caspases: structure, activation, substrates, and functions during apoptosis. Annu. Rev. Biochem. 68: 383-424

2. Deveraux QL and Reed JC (1999) IAP family proteins-suppressors of apoptosis. Genes Dev. 13: 239-252

3. Verhagen AM, Coulson EJ and Vaux DL (2001) Inhibitor of apoptosis proteins and their relatives: IAPs and other BIRPs. Genome Biol. 2

4. Chai J, Shiozaki E, Srinivasula SM, Wu Q, Dataa P, Alnemri ES and Shi Y (2001) Structural basis of caspase-7 inhibition by XIAP. Cell 104: 769-780
5. Huang Y, Park YC, Rich RL, Segal D, Myszka DG and Wu H (2001) Structural basis of caspase inhibition by XIAP: differential roles of the linker versus the BIR domain. Cell 104: 781-790

6. Riedl SJ, Renatus M, Schwarzenbacher R, Zhou Q, Sun C, Fesik SW, Liddington RC and Salvesen GS (2001) Structural basis for the inhibition of caspase-3 by XIAP. Cell 104: 791-800

7. Srinivasula SM, Hegde R, Saleh A, Datta P, Shiozaki E, Chai J, Lee RA, Robbins PD, Fernandes-Alnemri T, Shi Y and Alnemri ES (2001) A conserved XIAPinteraction motif in caspase-9 and Smac/DIABLO regulates caspase activity and apoptosis. Nature 410: 112-116

8. Verhagen AM, Ekert PG, Pakusch M, Silke J, Connolly LM, Reid GE, Moritz RL, Simpson RJ and Vaux DL (2000) Identification of DIABLO, a mammalian protein that promotes apoptosis by binding to and antagonizing IAP proteins. Cell 102: $43-53$

9. Du C, Fang M, Li Y, Li L and Wang X (2000) Smac, a mitochondrial protein that promotes cytochrome $\mathrm{c}$-dependent caspase activation by eliminating IAP inhibition. Cell 102: 33-42

10. Wu G, Chai J, Suber TL, Wu JW, Du C, Wang X and Shi Y (2000) Structural basis of IAP recognition by Smac/DIABLO. Nature 408: 1008-1012

11. Chai J, Du C, Wu JW, Kyin S, Wang $X$ and Shi $Y(2000)$ Structural and biochemical basis of apoptotic activation by Smac/DIABLO. Nature 406: 855862.

12. Liu Z, Sun C, Olejniczak ET, Meadows RP, Betz SF, Oost T, Herrmann J, Wu JC and Fesik SW (2000) Structural basis for binding of Smac/DIABLO to the XIAP BIR3 domain. Nature 408: 1004-1008

13. Krammer PH (2000) CD95's deadly mission in the immune system. Nature 407: $789-795$

14. Van Loo G, Demol H, van Gurp M, Hoorelbeke B, Schotte P, Beyaert R, Zhivotovsky B, Gevaert K, Declercq W, Vandekerckhove J and Vandenabeele P A matrix-assisted laser desorption ionization post-source decay (MALDI-PSD) analysis of proteins released from isolated liver mitochondria treated with recombinant truncated Bid. Cell Death Differ. in press.

15. Hu SI, Carozza M, Klein M, Nantermet P, Luk D and Crowl RM (1998) Human $\mathrm{HtrA}$, an evolutionarily conserved serine protease identified as a differentially expressed gene product in osteoarthritic cartilage. J. Biol. Chem. 273: 3440634412

16. Faccio L, Fusco C, Chen A, Martinotti S, Bonventre JV and Zervos AS (2000) Characterization of a novel human serine protease that has extensive homology to bacterial heat shock endoprotease $\mathrm{Htr}$ and is regulated by kidney ischemia.J. Biol. Chem. 275: 2581-2588

17. Gray CW, Ward RV, Karran E, Turconi S, Rowles A, Viglienghi D, Southan C, Barton A, Fantom KG, West A, Savopoulos J, Hassan NJ, Clinkenbeard H, Hanning C, Amegadzie B, Davis JB, Dingwall C, Livi GP and Creasy CL (2000) Characterization of human HtrA2, a novel serine protease involved in the mammalian cellular stress response. Eur. J. Biochem. 267: 5699-5710

18. Gevaert K, Demol H, Martens L, Hoorelbeke B, Puype M, Goethals M, Van Damme J, De BoeckS and Vandekerckhove J (2001) Protein identification based on matrix assisted laser desorption/ionization-post source decay-mass spectrometry. Electrophoresis 22: 1645-1651

19. Claros MG and Vincens $P$ (1996) Computational method to predict mitochondrially imported proteins and their targeting sequences. Eur. J. Biochem. 241: 779-786

20. LiH, Zhu H, Xu CJ and Yuan J (1998) Cleavage of BID by caspase 8 mediates the mitochondrial damage in the Fas pathway of apoptosis. Cell 94: 491-501

21. Luo X, Budihardjo I, Zou H, SlaughterC and Wang X (1998) Bid, a Bcl2 interacting protein, mediates cytochrome $c$ release from mitochondria in response to activation of cell surface death receptors. Cell 94: 481-490

22. Vercammen D, Vandenabeele P, Beyaert R, Declercq W and Fiers W (1997) Tumour necrosis factor-induced necrosis versus anti-Fas-induced apoptosis in L929 cells. Cytokine 9: 801-808

23. Denecker G, Vercammen D, Steemans $M$, Vanden Berghe T, Brouckaert G, Van Loo G, Zhivotovsky B, Fiers W, Grooten J, Declercq W and Vandenabeele P (2001) Death receptor-induced apoptotic and necrotic cell death: Differential role of caspases and mitochondria. Cell. Death. Differ. 8: 829-840

24. Savopoulos JW, Carter PS, Turconi S, Pettman GR, Karran EH, Gray CW, Ward RV, Jenkins $O$ and Creasy CL (2000) Expression, purification, and functional analysis of the human serine protease HtrA2. Protein Expr. Purif. 19: 227-234 
25. Kroemer G and Reed JC (2000) Mitochondrial control of cell death. Nat. Med. 6 $513-519$

26. Liu X, Kim CN, Yang J, Jemmerson R and Wang X (1996) Induction of apoptotic program in cell-free extracts: requirement for dATP and cytochrome $c$. Cell 86 $147-157$

27. Susin SA, Lorenzo HK, Zamzami N, Marzo I, Snow BE, Brothers GM, Mangion J, Jacotot E, Costantini P, Loeffler M, Larochette N, Goodlett DR, Aebersold R, Siderovski DP, Penninger JM and Kroemer G (1999) Molecular characterization of mitochondrial apoptosis-inducing factor. Nature 397: 441-446

28. Van Loo G, Schotte P, van Gurp M, Demol H, Hoorelbeke B, Gevaert K Rodriguez I, Ruiz-Carrillo A, Vandekerckhove J, Declercq W, Beyaert R and Vandenabeele $P$ Endonuclease $G$ : a mitochondrial protein released in apoptosis and involved in caspase-independent DNA degradation. Cell Death Differ. in press.

29. Li LY, Luo $X$ and Wang $X$ (2001) Endonuclease $G$ is an apoptotic DNase when released from mitochondria. Nature 412: $95-99$

30. Spiess C, Beil A and Ehrmann M (1999) A temperature-dependent switch from chaperone to protease in a widely conserved heat shock protein. Cell 97: 339 347
31. Suzuki Y, Imai Y, Nakayama H, Takahashi K, Takio Kand Takahashi R (2001) A serine protease, $\mathrm{Htr}$ 2, is released from the mitochondria and interacts with XIAP, inducing cell death. Mol. Cell 8: 613-621

32. Wright SC, Schellenberger U, Wang H, Kinder DH, Talhouk JW and Larrick JW (1997) Activation of CPP32-like proteases is not sufficient to trigger apoptosis: inhibition of apoptosis by agents that suppress activation of AP24, but not CPP32-like activity. J. Exp. Med. 186: 1107-1117

33. Kagaya S, Kitanaka C, Noguchi K, Mochizuki T, Sugiyama A, Asai A, Yasuhara $\mathrm{N}$, Eguchi $\mathrm{Y}$, Tsujimoto $\mathrm{Y}$ and Kuchino $\mathrm{Y}$ (1997) A functional role for death proteases in s-Myc- and c-Myc-mediated apoptosis. Mol. Cell. Biol. 17: 67366745

34. Rodriguez I, Matsuura K, Khatib K, Reed JC, Nagata S and Vassalli P (1996) A bcl-2 transgene expressed in hepatocytes protects mice from fulminant liver destruction but not from rapid death induced by anti-Fas antibody injection. J. Exp. Med. 183: 1031-1036

35. Van de Craen M, Declercq W, Van den brande I, Fiers W and Vandenabeele P (1999) The proteolytic procaspase activation network: an in vitro analysis. Cell Death Differ 6: 1117-1124 